УДК 784.3 (477)

DOI https://doi.org/10.31723/2524-0447-2021-32-1-11

Лу Тунцзе

ORCID: 0000-0003-1451-8129

аспірантка кафедри теорії та історії музики

Харківської державної академії культури

383517533@qq.com

\title{
МЕНТАЛЬНІ ДЕТЕРМІНАНТИ СУЧАСНОЇ УКРАЇНСЬКОЇ КАМЕРНО-ВОКАЛЬНОЇ МУЗИКИ НА ВІРШІ ЯПОНСЬКИХ ТА КИТАЙСЬКИХ ПОЕТІВ
}

Метою роботи є виявлення особливостей художнього втілення ментального резонансу української та східної картин світу в сучасний українській камерно-вокальній музиці на вірші японських та китайських митців. Методологія статті спирається на настанови компаративного, культурологічного, історико-культурного методів, аналітичного підходу із застосуванням музикознавчого методологічного інструментарію.

Наукова новизна розвідки зумовлена периферійністю в сучасному музикознавчому дискурсі питань специфіки резонування маркерів східного та українського ментального світів в українській камерно-вокальній музиці, яке позначено актуалізацією за умов глобалізаційних $і$ глокалізаційних процесів та активізації міжкультурного діалогу.

Висновки. У статті окреслено ментальний резонанс у східній картині світу таких характерних для української ментальності світоглядно-концептуальних акцентів вокального циклу Б. Лятошинського, як замилування старовиною, інтровертність і поетизація символів природи. Наголошено на активізації опанування східної поезії у творчості Ю. Тіщенка, І. Карабиия, Я. Верещагіна, Л. Грабовського, М. Колеси, що зумовлена інтенсифікацією уваги митців до філософської проблематики загальнолюдського масштабу та інтровертної ідентифікації в параметрах світової культури.

У контексті виявлення ментальних зв'язків поезії Сходу та української камерно-вокальної музики підкреслено такі характерні риси вокального ииклу М. Шуха, як психологізація жанру, інтровертний $i$ медитативний характери драматургї «станів», концептуальне значення звукопису, опосередковане відтворення маркерів народнопісенної манери та символів природи, культурна багатошаровість тембрової аури твору, суголосна поліфонічності української культури та постмодерністським тенденціям мультикультуралізму.

Акцентовано значення у втіленнях поезії Сходу таких суголосних ментальних конструктів національної картини світу тенденцій, як 
тембральне й звукописне оновлення камерно-вокального жанру, пов'язане з українським пантеїзмом (у творчості Д. Клебанова); суб'єктивізація творчого світу, котра резонує з українським індивідуалізмом (у творах С. Пілютикова, Б. Стронька, О. Рудянського, В. Польової, Р. Горобия, О. Яковчука); створення інтровертної й кордоцентричної позицій автора; поетизація символів природи (у творах I. Алексійчук, О. Рудянського), значення полілогу культур як аналог поліфонічного характеру української культури; медитативна, «нон-фабульна» драматургія, співвідносна з індивідуалізмом та інтровертністю національного світобачення (у творах О. Рудянського, О. Яковчука, Г. Саська). Як ментальні перетини української та східної картин світу в статті позиціоновано притаманні камерно-вокальним інтерпретаціям китайської та японської поезії у творчості українських композиторів лірична домінанта світобачення, медитативна інтровертність, рефлексивність, значущість та поетизація концепту Природи як світоглядного фундаменту та ціннісних основ Людини.

Ключові слова: камерно-вокальна музика, ментальні основи, національна картина світу, українська музика.

Lu Tongjie, Postgraduate Student at the Music Theory and History Department of the Kharkiv State Academy of Culture

Mental determinants of modern chamber and vocal music in poems of Japanese and Chinese poets

Research objective. The aim of the work is to identify the features of the artistic embodiment of the mental resonance between Ukrainian and Eastern worldview in modern chamber-vocal music on the poems by Japanese and Chinese artists. The methodology of the article is based on the instructions of comparative, culturological, historical and cultural methods, analytical approach using musicological methodological tools, etc.

The scientific novelty of article is due to periferality in modern musicological discourse on the specifics of resonance between markers Eastern and Ukrainian mental world in Ukrainian chamber-vocal music, which is marked be actualization under the conditions of globalization and glocalization processes activation of intercultural dialogue.

Conclusions. The article outlines the mental resonance between Eastern picture of world and such Ukrainian mentality characteristic in the worldviewconceptual accents of the vocal cycle be B. Lyatoshinsky as the conception of antiquity, introvertedness and poetic symbols of nature. Emphasize the intensification of the mastery of Oriental poetry in the works of Yu. Tishchenko, I. Karabits, Ya. Vereshchagin. L. Hrabovsky, M. Kolessa, which is due to the intensification of the attention of artists to the philosophical problems of universal human scale and introvert identification in the parameters of world culture.

In the context of identifying the mental connections between Eastern poetry and Ukrainian chamber-vocal music, are emphasized such characteristic features of M. Shukh as psyhologization og the genre, introverted, meditative nature of drama of «states», conceptual meaning of sound recording, indirect 
reproduction of folk-song manners markers and symbols of nature, the cultural multi-coloures timbre aura of the work, consistent with the polyphony of Ukrainian culture and postmodern tendencies of multiculturalism.

The impotence in the embodiment of Eastern poetry of such consonant mental constructs of the national picture of world trends as: timbre, sound update of chamber-vocal genre associated with Ukrainian pantheism (in the works of S. Pilyutikov, B. Stron'ko, O. Rudansky, V. Poleva, R. Horobets, $O$. Yakovchuk), creation of an introverted, cordocentric position of the author, poetization of nature symbols (in the works of I. Aleksiychuk, O. Rudansky), the value of polylogue of cultures as an analogue of the polyphonic nature of Ukrainian culture, meditative, "non-fabulous" drama, correlated with individualism and introverted national world versatility (in the works of O. Rudansky, O. Yakovchuk, G. Sas'ko).

As the mental intersections of the Ukrainian and Eastern picture of the world in the article are positioned inherent chamber-vocal interpretations of Chinese and Japanese poetry in the work of Ukrainian composers lyrical dominant of the worldview, meditative introvertedness, reflection, significance and poetization of the concept of Nature as a worldview foundation and value foundations of Man.

Key words: chamber-vocal music, mental foundations, national picture of world, Ukrainian music.

Актуальність теми дослідження. Культурний простір межі XX-XXI ст. демонструє суперечливе «накладання» глобалізаційних векторів, які мають культурно-уніфікувальне спрямування, та глокалізаційних, котрі виявляються «у різноспрямованих тенденціях мультикультуралізму, <..>> підвищенні значущості культури локусів (регіону, міста тощо), увазі до іiі самобутності та відродження автентичних джерел, актуалізації осягнення національного культурного досвіду та активізації процесів національної ідентифікації, інтенсифікації міжкультурної комунікації [12, с. 187]. За цих умов особливо актуальними є питання специфіки міжкультурної комунікації та особливостей ментальних детермінант національних художніх картин світу, зокрема української та східної, діалог між якими має давнє історичне коріння та стає одним із рушійних імпульсів у творчих пошуках українських композиторів сучасності.

Аналіз останніх досліджень і публікацій уможливлює констатацію значної інтенсифікації зацікавленості дослідників у висвітленні шляхів взаємовпливу східної та української музичних культур, зокрема в параметрах культури постмодернізму. Окреслена дослідницька лінія передбачає звернення до 
широкого кола питань, пов'язаних зі специфікою втілення китайської та японської поезії, котрі в різних дослідницьких ракурсах порушуються у розвідках таких дослідників, як Д. Азарова [1], О. Баланко [2], Ван Сі [3; 4], О. Гуркова [6], А. Дзюбан [7], О. Кушнірук [9], В. Редя [10], О. Рижова [11] та ін. Незважаючи на наявність потужної та масштабної «східної лінії в музикознавчому дискурсі останніх років, на периферії дослідницької уваги перебуває питання щодо специфіки відображення на рівні художньої рефлексії маркерів східного та українського ментального світів. Висвітлена у розвідках П. Гнатенка [5], С. Кримського [8], О. Кульчицького, Є. Онацького, В. Храмової, Б. Цимбалістого, М. Шлемкевича [13] проблематика ментальних обріїв української культури досі не стала тим дослідницьким фундаментом, на якому стає можливим висвітлення ментальних зв'язків української та східних культур та виявлення особливостей їх діалогу в українській камерно-інструментальній музиці межі XX-XXI ст., актуалізованого в контексті культурних реалій сучасності.

Окреслена дослідницька лакуна визначає актуальність цієї розвідки та зумовлює методологічну опору на настанови компаративного, культурологічного, історико-культурного методів, аналітичного підходу із застосуванням музикознавчого методологічного інструментарію тощо.

Метою статті $\epsilon$ виявлення особливостей художнього втілення ментального резонансу української та східної картин світу в сучасній українській камерно-вокальній музиці, зокрема на межі XX-XXI ст., на вірші японських та китайських митців. Новизна дослідження зумовлена відсутністю спеціальних розвідок 3 окресленого питання та водночас інтенсивністю репрезентації поезії східних авторів в естетичних вимірах української камерно-вокальної музики.

Виклад основного матеріалу. Камерно-вокальний жанр, традиційно позиціонований дослідниками як експериментальна площина, в котрій апробуються новації у художньо-виразній сфері, на межі XX-XXI ст. постає у плюралістичній множинності векторів розвитку. Одним із них є орієнталізувальна лінія, яка має давнє історичне коріння. В парадигмальних вимірах Нового часу «східні» концептуально-світоглядні, тематичні, емоційно-образні пошуки на рівні художньої рефлексії знаходили вираження в оперному театрі, надаючи йому «позаєвропейської» й казково-екзотичної видовищності 
[1, с. 7]. В контексті романтизму прагнення віднайти втрачені ідеали детермінувало створення не тільки східної аури оперного та балетного театру, а й звернення митців до безпосереднього уведення маркерів східного музичного мислення в контекст європейського музичного мистецтва, накладання ментально відмінних картин світу.

На поч. XX ст. імпульсом до формування самостійної національної камерно-вокальної орієнталізувальної лінії (зокрема на основі поезій китайських та японських митців) стали «Три романси на вірші китайських поетів» Б. Лятошинського (1925 р.), написані на основі поетичної творчості Лі Бо, Ван Вея, Цуй Гофу, вокальний цикл А. Рудницького «Китайська флейта», солоспів В. Балтаровича «Самотня дівчина». 3 цією лінією був опосередковано пов'язаний вокальний цикл I. Белзи «Фарфоровий павільйон. 5 китайських віршів на сл. М. Гумільова для одного голосу та фортепіано» («Луна та море», «Природа», «Щастя», «Єднання», «Серцю радісно»), створений у 1925-1926 рр. Д. Азарова зазначає, що в цей час «орієнталізм у західній музиці (зазначимо, що у цьому разі прецеденти звернення в українській музиці, зокрема до китайської та японської поезії, дослідниця висвітлює як належні саме до західноєвропейської художньої традиціï) є скоріше індивідуальним смаком, аніж загальною тенденцією» [1, с. 8].

Однак уже в одному з перших звернень до східної поезії в українській камерно-вокальній музиці («Трьох романсах на вірші китайських поетів» Б. Лятошинського («Старовинне», «У яшмових сходів», «Потік, де співає птах»)) наочно виявляється замилування старовиною (засвідчене авторським вибором вербальної основи твору), що створює ментальний резонанс із притаманною українській культурі акцентуацією минулого в ментальних параметрах національної картини світу.

Імпресіоністичні засади музичного мислення у вокальному циклі Б. Лятошинського (відповідно до пошукової атмосфери поч. XX ст.) злилися 3 експериментальними тенденціями щодо трансформації основ камерно-вокального жанру. 3 огляду на це, Ван Сі акцентує, що «підхід до камерно-вокального жанру як до вірша з музикою, своєрідного різновиду мелодекламації дали можливість, окрім музичного словника умовного орієнталізму, засобів імпресіонізму та сецесії, роз- 
крити й увиразнити світовідчуття, інтровертну статику та експресивність виразу» [4, с. 79], які безпосередньо виступають у статусі зв'язків із національною ментальністю.

На концептуальному рівні засобом такого зв'язку в циклі Б. Лятошинського $є$ «поетичний символ місяця як одного 3 найбільш стійких образів-констант поетичного бачення природи» [11, с. 424].

Сер. XX ст. була позначена певним «спалахом» зацікавленості українських митців до поезії Японії та Китаю. Звернення до поетичного світу Сходу було детерміновано вже не тільки їх «пряною екзотичністю». Вокальні цикли «Шість японських хоку» для голосу та камерного ансамблю (1964) та «Шість японських віршів» для сопрано й арфи (1971) Ю. Тіщенка, «3 пісень Хіросіми» I. Карабиця на сл. І. Йонеди (1971), «Три романси на вірші старовинних корейських поетів» Я. Верещагіна (1973), солоспіви «Японські хоку» Л. Грабовського на сл. Мацуо Басьо (1964 р), «У краю квітучої вишні» М. Колеси на сл. Ісікави Такубоку (1971) закарбували «прагнення композиторів почерпнути з шедеврів східної лірики теми та ідеї загальнолюдського звучання, філософської та етичної глибини. Східна інтровертність мислення виявилася близькою до внутрішньої потреби сучасного митця до моновисловлення, до поглибленого самоспоглядання, намагання осягнути своє «я», вільно конструюючи власний «космос» та інтуїтивно включаючись у цілісній потік генетичної інформації Світу» [10, c. 321].

1980-ті рр. стали новим етапом еволюції орієнталізувального напряму української камерно-вокальної музики, позначеного сутнісними зрушеннями у сфері музичної мови, інтерпретуванням жанрових основ камерно-вокального циклу, осягненням статусу та функцій вокального та інструментального шарів у його контексті, модифікуванням палітри засобів виразності та зміною їх ієрархії тощо.

Із новаторським інтерпретуванням камерно-вокального жанру в контексті орієнталізувальної лінії його розвитку у 1980-ті рр. пов'язаний вокальний цикл М. Шуха «Пісні весни» (1986), створений на сл. Бо Пу, Ван Хецина, Сюй Цзайси. Зазначена новаційність твору, що складається з чотирьох частин («Передчуття весни», «Радість весни», «Сум весни», «Звуки весни», «Спокій весни»), виявляється у напрямі психологізації жанру та створенні його «пейзажного» варіанта. 
Кожна з частин циклу, будучи окремим, цілісним, завершеним психологічним узірцем, є також необхідним компонентом-стадією безперервного та іманентного процесу духовного злиття з природою. Образ останньої постає як незримий концептуально-смисловий фундамент твору, слугуючи засобом зв’язку східної та української картин світу та єднаючи їх на ментальному рівні. В мовностильовому аспекті, в системі засобів виразності це виявляється в значущості звукопису (імітаційних фігурах ксилофона та флейти (спів птахів)), що співвідноситься з атрибутивною для українського фольклору ономатопеєю, на рівні вокального звуковидобування - у висотно нейтральних побудовах у вокальній партії, що асоціюється як із мовним звуковидобуванням, так і з аналогічними прийомами народного співу, як-от висотно невизначеними вигуками.

Медитативність та інтровертність як ментальні маркери української національної картини світу є тими чинниками, котрі іiі поєднують в інтегральну й універсальну цілісність зі східним образом світу. На рівні музичного мислення та темпорально-часових параметрів музичної тканини таке накладання ментальних конструктів у циклі М. Шуха виявляється як у просторово безмежній аурі твору, зумовленій октавним дублюванням інструментальних партій (зокрема в пісні «Звуки весни» - флейти та вібрафона), перегуками та мерехтіннями інтонаційних сплесків дзвоників, флейти, вібрафона тощо, так і в максимальному нівелюванні чіткого плину часу - свободі метрики (так, пісня «Туга весни» позначена униканням метричних позначок), тактового членування та виняткової значущості агогічних нюансів, за яких раціональність, часова впорядкованість та регулярність музичного мислення поступається місцем свободі емоційно-почуттєвого потоку.

Модифікування камерно-вокального жанру в «Піснях весни» М. Шуха реалізується в експериментальному, нетрадиційному єднанні інструментальних голосів, позначених власним культурним «шлейфом», зокрема й національним (флейта piccolo, вібрафон, ксилофон та масштабна група ударних, як-от там-там, трикутник, бонги, дзвони тощо). Зазначимо, що такий плюралізм тембрових засад твору, з одного боку, відповідає як постмодерністським тенденціям мультикультуралізму, прагненням до переформатування інструментальної ієрархії та набуття ритмом статусу одного з визначаль- 
них засобів виразності, з іншого - резонує з поліфонічністю української культури.

Однією з унікальних рис вокального циклу М. Шуха стає тенденція до переосмислення самої сутності вокального начала. Детермінантами новітнього трактування останнього є своєрідне дублювання та переосмислення функцій людського голосу в контексті камерно-вокального жанру. Так, «двійником» співу стає декламація, функціональні статуси співачки та чтиці є взаємопідмінюваними, адже вокальна партія насичена декламаційними інтонемами, тоді як декламація чтиці демонструє безумовне тяжіння до вокально-співочої сфери. Переосмислення специфіки вокального начала відбивається і в інструментальній іiі трансформації - насиченні партії співачки «тембральними звуконаслідуваннями, позакантиленними інтонаційними зворотами, вокалізами на відкритих звуKax i mormorando» [3, с. 145].

Тембральне оновлення камерно-вокального жанру яскрава ознака вокального циклу Д. Клебанова «Японські силуети» (на основі фрагментів зі збірки японського поета Масаока Сікі «Оголені дерева в зимових горах») для сопрано, віоли д’амур, фортепіано, флейти, фаготу, струнних та ударних, який забезпечує створення імпресіоністичної атмосфери вслуховування в звучання природи. Звукопис, поетизація плину пір року, концептуальна значущість уселенського зв'язку всього в природі (опосередковано реалізована на композиційно-структурному рівні в значущості варіантності, варіаційності, рондальності тощо) та її символів (зокрема птахів), що є смислотворчими для української та східної культури, - ті чинники, які в циклі створюють ментальний зв'язок між ними.

Інтенсивність новаційного трактування жанрових засад камерно-вокальної музики, системи засобів виразності, тембральності, суб'єктивізація творчого «прочитання східної поезії - атрибутивні ознаки українських версій східної поезії межі XX - поч. XXI ст. (вокальних циклів С. Пілютикова («Із японської поезії», 1991), Б. Стронька (для тенора та фортепіано, на вірші старовинних китайських поетів, 1994), О. Рудянського («Озеро білих лотосів», 2001) солоспіву «Хоку» В. Польової на сл. Кобаясі Ісса (1991), вокальних циклів І. Алексійчук «Пісні кохання» (7 солоспівів на слова зі збірки поезій стародавніх поетів «Старі та нові пісні Японії, 1996), Р. Горобця 
(на вірші японських поетів, 2009), О. Яковчука («Сливи цвіт» на сл. Мацуо Басьо, 2017)).

Резонанс східної та української ментальної картин світу у вокальному циклі I. Алексійчук знаходить відображення на концептуально-символічному рівні. Акцентуація пантеїстичних символів-концептів природи (серпанок, квіти, світанок, вода (гірський потік), птахи тошо) як визначальних ідейних конструктів, спираючись на які вибудовується інтровертний тип емоцій, зумовлює нерозривність синтезу ліричного начала та світу природи, що мають значення в окреслених національних картинах світу. Підкреслена О. Гурковою драматургічна та композиційно-структурна вагомість теми тремтіння серця $[6$, с. 116,121$]$ в проблемному дискурсі цієї розвідки постає як своєрідне відбиття українського кордоцентризму.

Акцентуація значущості концептів Води, Землі, Сонця, Гір як смислотворчих основ східної картини світу у вокальному циклі О. Рудянського «Озеро білих лотосів» створює яскраво виражений ментальний зв'язок із фундаментальними концептуальними опорами української ментальності, пов'язаними з пантеїстичним піднесенням природних стихій. Безумовна суголосність концепції твору українському менталітету та національній звуковій картині світу виявлена у винятковій індивідуалістичності інструментально-тембрового бачення камерно-вокального циклу.

Його «плюралістичність» детермінована асоціаціями-посиланнями на різні історичні та національні шари культури: флейта та альт як узірці західноєвропейської музичної традиціï, зокрема романтичної, позначеної емансипацією тембру альта; ударні інструменти, значущість яких у розгортанні музичної тканини та інструментальному образі твору резонує 3 емансипацією ритму в естетичних вимірах культури Новітнього часу; бандура як яскравий тембральний атрибут української культури, з одного боку, фольклорної - з іншого (з огляду на активність сучасного процесу академізації інструмента), як ознака синтезування-накладання академічного та фольклорного шарів у полікультурних вимірах сьогодення; голос як універсальний і позачасовий носій людського й особистісного начала в контексті історико-культурних епох та шарів культури.

3 огляду на специфіку багатовимірного культурного полілогу межі XX-XXI ст., В. Ущіпавська зазначає, що «постмо- 
дерністський діалог Сходу-Заходу в українській музиці виявляється не лише у зверненні до східних поетів і кола образів, а й у використанні принципів медитативності і рефлексивності як у відображенні світоглядних засад, так і в розгортанні музичних образів» [14, с. 259].

Унікальним за своєю виразністю та ментальною спорідненістю засобом зв'язку української та східної картин світу у вокальних циклах О. Руданського та Г. Саська є смислотворча за статусом «нон-подієва», «нефабульна» драматургія твору як художньої цілісності. Рефлексивно-медитативне занурення в буття природи, яке створює ефект уподібнення життя людини та життя природи, драматургія не дії, а особистісного вчування-«перебування»-єднання з нею, резонує з ментальними маркерами українського образу світу - індивідуалізмом та інтровертністю.

Масштабний вокальний цикл О. Яковчука «Сливи цвіт» (2017), створений на сл. Мацуо Басьо, демонструє тенденції жанрової модифікації (наближення жанру камерно-вокального циклу до моноопери) та переосмислення сутності драматургічного процесу. Подієвість, процесуальність замінюється медитативною сконцентрованістю кожного з 10-ти розділів - драматургією станів. Виразні зв'язки з ментальною українською інтровертністю та пантеїстичними світоглядними настановами створено композитором завдяки імпресіоністичній атмосфері, гармонічній колористичності, а також значущості звукопису - голосу Природи.

Висновки. Питання специфіки зв'язку ментальних світів української та східної культур та їх відображення на рівні художньої рефлексії є принципово відкритим. Перманентність розгортання культурного полілогу, тенденція до взаємопроникнення та взаємодетермінації культур за умов глобалізації та глокалізації є тим чинником, який забезпечує множинність творчого інтерпретування інонаціонального художнього доробку, що відповідає плюралістичності культури постмодернізму. Незважаючи на розмаїття творчих (зокрема експериментальних) репрезентацій східної (зокрема китайської та японської) поезії в естетичних вимірах української камерно-вокальної музики, видається можливим окреслити такі притаманні їм перетини ментальних зв'язків, як лірична домінанта світобачення, медитативна інтровертність, рефлексивність ліричного героя, а також особлива значущість 
і поетизація концепту Природи як світоглядного фундаменту особистості та площини розгортання пошуку ціннісних основ буття Людини. Формуючи підстави для осмислення сутності та векторів духовних і художніх пошуків у глокалізувальних спрямуваннях сучасного культурного процесу, висвітлення специфіки ментального резонансу української та східної культур в естетичних вимірах української камерно-вокальної музики, зокрема в новітній версії їх втілення - вокальному циклі Г. Саська «Строфы из граненой яшмы» (для меццо-сопрано та фортепіано, 2020 р., на сл. китайської поетки XI ст. Лі Цін-Чжао), становить перспективи подальших досліджень.

\section{СПИСОК ЛІТЕРАТУРИ}

1. Азарова Д. Діалог традицій Сходу і Заходу в музиці постмодернізму. Студії мистецтвознавчі. Київ : Інститут мистецтвознавства імені М.Т. Рильського НАН України, 2018 № 3. С. 7-31.

2. Баланко О.М. Українська камерно-вокальна музика кінця XX - XXI ст. як виконавський феномен : автореф. дис. ... канд. Мистецтвознавства : 17.00.03 / Одеська нац. муз. акад. ім. А.В. Нежданової. Одеса, 2017. 19 с.

3. Ван Сi. Поезія Китаю в українській камерно-вокальній музиці постмодерної доби (на прикладі «Пісень весни» М. Шуха»). Наукові збірки ЛНМІ ім. М. В. Лисенка «Музикознавчі студї». 2012. Вип. 26. C. $137-146$.

4. Ван Сi. Рівні прояву інтертекстуального семіозису у вокальному циклі «Три вірші старовинних китайських поетів VIII століття» Б. ЛЯтошинського. Наукові збірки ЛНМІ ім. М. В. Лисенка «Музикознавчі студї». 2013. Вип. 27. С. 70-81.

5. Гнатенко П.І. Український національний характер. Київ : «ДОК-К», 1997. 116 с.

6. Гуркова О.М. Творчість І. Карабиця в контексті жанровостильових тенденцій в українській музиці останньої третини XX століття : дис. ... канд. мистецтвознавства : 17. 00.03/ НМАУ ім. П.I. Чайковського. Київ, 2016. 324 с.

7. Дзюбан А. Жанр хокку в камерно-вокальном цикле Дмитрия Клебанова «Японские силуэты». Науковий вісник НМАУ ім. П.І. Чайковського. 2013. Вип. 106. С. 281-299.

8. Кримський С.Б. Під сигнатурою Софії. Київ : Вид. дім «Києво-Могилянська академія», 2008. 367 с.

9. Кушнірук О. Стильові особливості вокальних циклів О. Яковчука. Часопис Національної музичної академії ім. П. І. Чайковського. 2020. № 2-3 (47-48). С. 67-79.

10. Редя В.Я. Тема «Схід-Захід» у сучасній українській музиці: пошук нових стильових синтезів. Українська культура в контексті сучасних наукових досліджень та практичних реалій : матеріали Все- 
української науково-практичної конференції (м. Київ, 21-22 грудня 2006 р.). Київ, 2007. Ч. 2. С. 320-324.

11. Рижова О.О. Китайська тема в німецькому й українському символізмі (на прикладі порівняння інструментальної фактури в «Пісні про землю» Г. Малера й циклу на вірші китайських поетів Б. Лятошинського). Вісник НАKККМ. 2019. № 2. С. 420-425.

12. Уманець О. В. Глокалізація. Соціологія права : енциклопедичний словник / за ред. М.П. Требіна. Харків : Право, 2020. С. 186-188.

13. Українська душа. Київ : Фенікс, 1992. 128 с.

14. Ущапівська О.М. Творчість донецьких композиторів у контексті соціокультурної ситуації сучасності. Актуальні проблеми історії, теорії та практики художньої культури. 2009. Вип. XXII. С. 257-265.

\section{REFERENCES}

1. Azarova, D. (2018). Dialog tradytsiy Skhodu ta Zakhodu v musytsi postmodernizmu [Dialogue of East and West traditions in the music of postmodernism]. Studiyi mystetstvoznavchi - Researches of the Fine Arts, 3 (63). 7-31 [in Ukrainian].

2. Balanko, O. M. (2017). Ukrayins'ka kamerno-vokal’na musica kintsya XX - XXI ст. yak vykonavs'kiy phenomen [Ukrainian chamber-vocal music of the late XX - early XXI centuries as a performing phenomenon]. Extended abstract of candidate's thesis. Odesa: The Odesa National A. V. Neshdanova Musical Academy [in Ukrainian].

3. Vang Xi (2012). Poesiya Kytayu v ukrayins'kiy kamerno-vokal'niy musytsi postmodernoyi doby (na prykladi "Pisen` vesny" M. Shukha) [Poetry in Chinese Ukrainian chamber music, postmodern time (for example "Songs of Spring" M. Shukh)]. Naukovi znirky LNMI im. M. V. Lysenka "Musykoznavchi studiyi" - Collection of Scientific Articles of the M. V. Lysenko National Music Academy of Lviv, 26,137-146 [in Ukrainian].

4. Vang Xi (2013). Rivni proyavu intertekstual'nogo semiosysu u vocal'nomu tsykli "Try virshi starovynnykh kytayis"kykh poetiv VIII stolittya" B. Lyatoshyns'kogo [Levels of manifestation of intertextual semiotic in vocal cycle "Three poems of ancient Chinese poets of the $8^{\text {th }}$ century" Boris Liatoshynsky]. Naukovi znirky LNMI im. M. V. Lysenka "Musykoznavchi studiyi" - Collection of Scientific Articles of the M. V. Lysenko National Music Academy of Lviv,26, 70-81[in Ukrainian].

5. Hnatenko, P. I. (1997). Ukrayins'kiy nationalnyi kharakter [Ukrainian national character]. Kyiv: «DOK-K» [in Ukrainian].

6. Hurkova, O. M. (2016). Tvorchist' I. Karabytsya v kontexti janrovo-ctyl’ovykh tendentsiy v ukrayins'kiy musitsi ostannyoyi tretyny XX stolittya [The work of I. Karabyts in the context of genre and stylistic tendencies in Ukrainian music of the last third of the $20^{\text {th }}$ century]. Candidate's thesis. Kyiv: UNTAM [in Ukrainian].

7. Dzyuban, A. (2013). Janr khokku v kamerno-vokal'nom tsicle Dmitriya Klebanova «Yaponskiye siluety» [The Genre of Haiku in the Chamber Vocal Cycle "Japanese silhouettes" by Dmytro Klebanov]. Nau- 
kovyi visnyk NMAU im. P. I. Tchaikovs'kogo - Scientific Herald of Tchaikovsky National Music Academy of Ukraine, 106, 281-299 [in Russian].

8. Kryms'ky, S. B. (2008). Pid signaturoyu Sophiyi [Under signature of Sophia]. Kyiv: Vyd. dim «Kyevo-Mogylyans`ka academiya» [in Ukrainian].

9. Kushniruk, O. (2020). Stylyovi osoblyvosti vocal'nykh tsykliv O. Yakovchuka [Style features of the vocal cycles by Alexander Jacobchuk]. Chasopys Natsionalnoyi musichnoyi academiyi im. P. I. Tchaikovskogo Journal of Tchaikovsky National Music Academy of Ukraine, 2-3 (47-48). 67-79 [in Ukrainian].

10. Redya, V. Ya. (2007). Thema «Skhid-Zakhid» u suchasniy ukrayins'kiy musytsi: poshuk novykh styl'ovykh syntesiv [Theme East-West in contemporary Ukrainian music6 the search for new stylistic syntheses]. Proceedings from: Vseukayins ka naukovo-praktychna koferentsiya «Ukrayins'ka kul'tura $v$ kontekste suchasnykh naukovykh doslidshen' ta praktychnykh realiy» - The All-Ukrainian Scientific and Practical Conference «Ukrainian Culture in the context of modern scientific research and practical realities» (Vols.2). (pp. 320-324). Kyiv [in Ukrainian].

11. Ryzhova, O. (2019). Kytays`ka thema v nimets`komu yi ukrayins 'komu symvolizmi (na prykladi porivnyannya instrumental'noyi faktury v «Pisni pro zemlyu» G. Mahlera ui tsyklu na virshi kytays`kikh poetiv B. Lyatoshins'kogo) [Chinese theme in German and Ukrainian symbolism (on example of the comparison of the invoice in "Canto about Land" of G. Mahler and cycle on verses of Chinese poets of B. Ljatoshinsky)]. Visnyk NAKKCaM - National Academy of Managerial Staff of Culture and Arts Herald, 2, 420-425 [in Ukrainian].

12. Umanets, O. V. (2020). Glokalisatsiya [Glocalisation]. Sotsiologiya prava: entsiklopedychnyi slovnyk - Sociology of Law: encyclopedic dictionary. M. P. Trebin (Ed.). (pp. 186- 188). Kharkiv: Pravo [in Ukrainian].

13. Khramova, V. (Eds.) (1992). Ukrayins'ka dusha [Ukrainian soul]. Kyiv: Pheniks [in Ukrainian].

14. Ushchapivs`ka, O. M. (2009). Tvorchist' donets'kikh u konteksti sotsiokul'turnoyi sytuatsiyi suchasnosti [Creativity of Donetsk composers in the context of the socio-cultural situation of the present]. Actual'ni problem istoriyi, theoriyi ta praktyky khudojn'oyi cul'tury - Topical Problems of History, Theory and Practice if Artistic Culture, XII, 257-265 [in Ukrainian]. 